\title{
Lack of association between CGRP-related gene polymorphisms and medication overuse headache in migraine patients
}

\author{
Masakazu Ishii ${ }^{1 *}$, Hirotaka Katoh ${ }^{2}$, Tatsuya Kurihara ${ }^{1}$, Ken-ichi Saguchi ${ }^{3}$, Shunichi Shimizu ${ }^{1,4}$ and Mitsuru Kawamura $^{2}$ \\ ${ }^{1}$ Department of Pharmacology, Toxicology and Therapeutics, Division of Physiology and Pathology, Showa University School of Pharmacy, Tokyo 142-8555, Japan \\ ${ }^{2}$ Department of Neurology, Showa University School of Medicine, Tokyo 142-8666, Japan \\ ${ }^{3}$ Department of Pharmacy Education, Showa University School of Pharmacy, Tokyo 142-8555, Japan \\ ${ }^{4}$ Laboratory of Pharmacology, Department of Clinical Pharmacy, Yokohama College of Pharmacy, Yokohama 245-0066, Japan
}

\begin{abstract}
We investigated whether calcitonin gene-related peptide (CGRP)-related gene polymorphisms are involved in the aggravation of migraines due to medication overuse. In total, 47 migraine patients ( 6 males and 41 females; $36.4 \pm 10.3$ years) and 22 medication overuse headache $(\mathrm{MOH})$ patients $(1 \mathrm{male}$ and 21 females; $39.6 \pm 9.9$ years) who had migraine participated in this study. Calcitonin gene-related polypeptide-alpha (CALCA, $\alpha$-CGRP, Insertion/Deletion rs1553005, rs145837941) and CGRP receptor (receptor activity-modifying protein 1: RAMP1, rs3754701, rs7590387) were analyzed by polymerase chain reaction (PCR) and PCR-restriction fragment length polymorphism (PCR-RFLP) methods. No significant differences were observed in the genotype distributions of CALCA and RAMP1 between migraine patients and MOH patients. The results of this study showed no association between CGRP-related gene polymorphisms and the complication of $\mathrm{MOH}$ in migraine patients.
\end{abstract}

\section{Introduction}

Migraine patients are particularly prone to developing medication overuse headache $(\mathrm{MOH})$ [1-3]. Moreover, it has been shown that $56.8 \%$ of migraine sufferers use over-the-counter medicine alone [4]. Although $\mathrm{MOH}$ is known to be caused by triptan, ergotamine, opioid, and/or analgesic overuse in patients with headache [1], 85.1\% of $\mathrm{MOH}$ patients overuse combination analgesics according to research by Imai et al. [2]. Most patients return to an episodic migraine pattern following drug withdrawal. However, the complication of $\mathrm{MOH}$ markedly decreases the quality of life of these patients [1]. In addition, the incidence of comorbidity with depression is higher in $\mathrm{MOH}$ patients than in migraine patients $[3,5]$. Therefore, the aggravation of migraines due to medication overuse needs to be prevented.

Calcitonin gene-related polypeptide-alpha (CALCA, a-CGRP) is a potent vasodilator and one of the mediators of neurogenic inflammation. Plasma levels of calcitonin gene-related peptide (CGRP), later called $\alpha$-CGRP, are elevated in migraine patients [6,7], and an infusion of CGRP can trigger a migraine attack [8]. In addition, CGRP antagonists have good efficacy in the treatment of acute migraine attacks $[9,10]$. Thus, CGRP is a key molecule in migraine pathogenesis. Interestingly, in $\mathrm{MOH}$ model animals, triptan increased CGRP levels [11]. In addition, exposure to $\mu$ opioids such as morphine also increased CGRP in cultured dorsal root ganglion cells $[12,13]$. Therefore, increasing CGRP through medication overuse seems to aggravate migraines.. On the other hand, Menson et al. [14] showed no significant association between the intronic 16 bp deletion in the CALCA gene and migraine. Sutherland et al. [15] also reported that CALCA polymorphisms (rs3781719, rs145837941) and CGRP receptor (receptor activity-modifying protein 1: RAMP1, rs3754701, rs7590387) are not involved in the pathogenesis of migraine. However, to the best of our knowledge, there have been no studies on the relationship between CGRP-related gene polymorphisms and $\mathrm{MOH}$.

In present study, we focused on CGRP-related gene polymorphisms such as CALCA and RAMP1 and investigated the relationship between CGRP-related gene polymorphisms and the complication of $\mathrm{MOH}$ in migraine patients.

\section{Methods}

\section{Subjects}

We enrolled 47 migraine patients [ 6 males and 41 females: 5 with migraines with aura (MA), 36 with migraines without aura (MO), 6 with both MA and MO at different times; $36.4 \pm 10.3$ years of age] and $22 \mathrm{MOH}$ patients who had migraine (1 male and 21 females: 1 with MA and 21 with MO; $39.6 \pm 9.9$ years of age) who were seen in an outpatient clinic of the Department of Neurology, Showa University

Correspondence to: Masakazu Ishii, Ph.D, Department of Pharmacology, Toxicology and Therapeutics, Division of Physiology and Pathology, Showa University School of Pharmacy, 1-5-8 Hatanodai, Shinagawa-ku, Tokyo 142-8555, Japan; Tel: +81-3-3784-8041; Fax: +81-3-3786-0481; E-mail: masakazu@pharm.showa-u.ac.jp

Key words: medication overuse headache, migraine, polymorphism, calcitonin gene-related peptide

Received: January 01, 2015; Accepted: January 10, 2015; Published: January 14, 2015 
East Hospital, Tokyo, Japan, between May 2010 and January 2011. These subjects were the same as those included in a previous study [16]. The incidence of depression was significantly higher in $\mathrm{MOH}$ patients than in migraine patients $(p<0.001)$ [16]. The medications that were overused were combination analgesics in 14 patients (64\%), analgesics in 9 patients (41\%), and triptans in 2 patients (9\%) [16].

Migraines were diagnosed according to the International Classification of Headache Disorders, 2nd Edition (ICHD-II), 2004 [17]. We also confirmed by interview that migraine patients did not overuse headache medications. The revised ICHD-II criteria were used to diagnose $\mathrm{MOH}$ [1]. $\mathrm{MOH}$ patients were questioned about their primary headaches by headache specialists. In addition, these headache specialists confirmed the primary headache according to the ICHD-II criteria after treating $\mathrm{MOH}$. Although the subjects of the present study included not only patients with migraines but also patients with migraines and tension-type headaches, patients with tension-type headaches were excluded. We used the Diagnostic and Statistical Manual of Mental Disorders, Fourth Edition (DSM-IV) [18] to diagnose major depressive disorder.

All patients were Japanese. All patients who provided informed consent, including those with migraines and the subset with $\mathrm{MOH}$, were enrolled in the study. This clinical study was approved by the Ethics Committee for Genome Research of Showa University.

\section{Genotyping}

Genomic DNA was extracted from whole blood using NucleoSpin ${ }^{\circledR}$ Blood QuickPure (NIPPON Genetics Co., Ltd., Tokyo, Japan). The gene polymorphisms of CGRP (Insertion/Deletion (I/D) [14], rs1553005, rs145837941) and RAMP1 (rs3754701, rs7590387) [15] were studied. The polymorphism of each gene was determined by polymerase chain reaction (PCR) and PCR-restriction fragment length polymorphism (PCR-RFLP) methods. Primer sequences, restriction enzymes, and expected fragment sizes of the gene polymorphisms are shown in Table 1. The PCR products or restriction enzyme-treated PCR fragments were run on $3 \%$ agarose gels and stained with ethidium bromide.

\section{Statistical analysis}

Categorical variables were analyzed by $\chi^{2}$ test or Fisher's exact test using Excel Statistics 2008 for Windows (Excel Toukei, Social Survey Research Information Co., Tokyo, Japan). $p$ values $\leq 0.05$ were considered significant.

Table 1: Primers and restriction enzymes used for genotyping.

\begin{tabular}{|c|c|c|c|c|}
\hline \multicolumn{2}{|c|}{ Polymorphism } & \multirow{2}{*}{\begin{tabular}{|c|} 
Primer \\
5'-TTG GGG AGA AGG GTA GGA CT-3'
\end{tabular}} & \multirow{3}{*}{\begin{tabular}{|l|}
$\begin{array}{l}\text { Restriction } \\
\text { enzyme }\end{array}$ \\
- \\
\end{tabular}} & \multirow{2}{*}{$\begin{array}{l}\text { Product } \\
\text { size (bp) }\end{array}$} \\
\hline \multirow{6}{*}{ CALCA } & \multirow[b]{2}{*}{$\mathrm{I} / \mathrm{D}$} & & & \\
\hline & & 5'-GAA CTT TTG GAA GCC CAT GA-3' & & D: 287 \\
\hline & \multirow[b]{2}{*}{ rs 1553005} & 5'-TAG CTG GTA TTA CCC ACA GAG-3' & \multirow[b]{2}{*}{ Bsu36I } & G: 167 \\
\hline & & 5'-CCC ATT TCA AAG ATG AGT ACCCTG-3' & & $\begin{array}{l}\text { C: } 142 \\
\text { and } 25\end{array}$ \\
\hline & \multirow[b]{2}{*}{ rs145837941 } & 5'-TGA ACA ACA CAG CCT GTT GG-3' & \multirow[b]{2}{*}{ AluI } & G: 252 \\
\hline & & 5'-TGG AGA GCA GCC CAG CAG AC-3' & & $\begin{array}{l}\text { A: } 151 \\
\text { and } 101\end{array}$ \\
\hline \multirow{4}{*}{ RAMP1 } & \multirow[b]{2}{*}{ rs 3754701} & 5'-TGG CCT CTC GGC ATT ACT G-3' & \multirow[b]{2}{*}{ AclI } & T: 373 \\
\hline & & 5'-TGC ACA GGT GGT AGG CAT G-3' & & $\begin{array}{l}\text { A: } 215 \\
\text { and } 158\end{array}$ \\
\hline & \multirow[b]{2}{*}{ rs7590387 } & 5'-AGA GCC TGT CGT TGT GCC CA-3' & \multirow[b]{2}{*}{$\mathrm{XcmI}$} & G: 284 \\
\hline & & 5'-CTC CCG TCT CCT CGC CCT CA-3' & & $\begin{array}{l}\text { C: } 194 \\
\text { and } 90\end{array}$ \\
\hline
\end{tabular}

Table 2. Genotype distribution of gene polymorphisms.

\begin{tabular}{|c|c|c|c|c|c|c|c|}
\hline & & & $\begin{array}{c}\text { Migraine } \\
\mathrm{n}=47\end{array}$ & $(\%)$ & $\begin{array}{c}\text { MOH } \\
n=22\end{array}$ & $(\%)$ & $P$ value \\
\hline \multirow[t]{15}{*}{ CALCA } & $\mathrm{I} / \mathrm{D}$ & $\mathrm{I} / \mathrm{I}$ & 47 & 100.0 & 22 & 100.0 & \\
\hline & & $\mathrm{I} / \mathrm{D}$ & 0 & 0.0 & 0 & 0.0 & \\
\hline & & $\mathrm{D} / \mathrm{D}$ & 0 & 0.0 & 0 & 0.0 & \\
\hline & & $\mathrm{I} / \mathrm{I}$ & 47 & 100.0 & 22 & 100.0 & 1.000 \\
\hline & & $\mathrm{I} / \mathrm{D}, \mathrm{D} / \mathrm{D}$ & 0 & 0.0 & 0 & 0.0 & \\
\hline & rs 1553005 & $\mathrm{G} / \mathrm{G}$ & 22 & 46.8 & 9 & 40.9 & \\
\hline & & $\mathrm{G} / \mathrm{C}$ & 18 & 38.3 & 10 & 45.5 & \\
\hline & & $\mathrm{C} / \mathrm{C}$ & 7 & 14.9 & 3 & 13.6 & \\
\hline & & $\mathrm{G} / \mathrm{G}$ & 22 & 46.8 & 9 & 40.9 & 0.646 \\
\hline & & $\mathrm{G} / \mathrm{C}, \mathrm{C} / \mathrm{C}$ & 25 & 53.2 & 13 & 59.1 & \\
\hline & rs145837941 & $\mathrm{A} / \mathrm{A}$ & 47 & 100.0 & 22 & 100.0 & \\
\hline & & $\mathrm{A} / \mathrm{G}$ & 0 & 0.0 & 0 & 0.0 & \\
\hline & & $\mathrm{G} / \mathrm{G}$ & 0 & 0.0 & 0 & 0.0 & \\
\hline & & $\mathrm{A} / \mathrm{A}$ & 47 & 100.0 & 22 & 100.0 & 1.000 \\
\hline & & $\mathrm{A} / \mathrm{G}, \mathrm{G} / \mathrm{G}$ & 0 & 0.0 & 0 & 0.0 & \\
\hline \multirow[t]{10}{*}{ RAMP1 } & rs 3754701 & $\mathrm{~A} / \mathrm{A}$ & 18 & 38.3 & 10 & 45.5 & \\
\hline & & $\mathrm{A} / \mathrm{T}$ & 20 & 42.6 & 8 & 36.4 & \\
\hline & & $\mathrm{T} / \mathrm{T}$ & 9 & 19.1 & 4 & 18.2 & \\
\hline & & $\mathrm{A} / \mathrm{A}$ & 18 & 38.3 & 10 & 45.5 & 0.573 \\
\hline & & $\mathrm{A} / \mathrm{T}, \mathrm{T} / \mathrm{T}$ & 29 & 61.7 & 12 & 54.5 & \\
\hline & rs7590387 & $\mathrm{G} / \mathrm{G}$ & 22 & 46.8 & 13 & 59.1 & \\
\hline & & $\mathrm{G} / \mathrm{C}$ & 23 & 48.9 & 8 & 36.4 & \\
\hline & & $\mathrm{C} / \mathrm{C}$ & 2 & 4.3 & 1 & 4.5 & \\
\hline & & $\mathrm{G} / \mathrm{G}$ & 22 & 46.8 & 13 & 59.1 & 0.342 \\
\hline & & $\mathrm{G} / \mathrm{C}, \mathrm{C} / \mathrm{C}$ & 25 & 53.2 & 9 & 40.9 & \\
\hline
\end{tabular}

\section{Results}

The genotype distributions of polymorphisms of the CALCA (Insertion/Deletion, I/I vs. I/D plus D/D, $p=1.000 ;$ rs1553005, G/G vs. G/C plus C/C, $p=0.646 ;$ rs145837941, A/A vs. A/G plus $\mathrm{G} / \mathrm{G}, p=1.000$ ) and RAMP1 (rs3754701, A/A vs. A/T plus T/T, $p=0.573$; rs7590387; $\mathrm{G} / \mathrm{G} v s$. G/C plus $\mathrm{C} / \mathrm{C}, p=0.342$ ) genes were not significantly different between migraine patients and $\mathrm{MOH}$ patients (Table 2).

\section{Discussion}

We previously reported that gene polymorphisms such as methylenetetrahydrofolate reductase (rs1801133) and dopamine D2 receptor (rs6275) were associated with the complication of $\mathrm{MOH}$ in migraine patients [16], in addition to the tumor necrosis factor (TNF)- $\beta$ gene polymorphism [20]. Thus, gene polymorphisms that are unrelated to 5-hydroxytryptamine seem to be associated with the aggravation of migraines by medication overuse.

In the present study, we focused on the relationship between CGRP-related gene polymorphisms and the complication of $\mathrm{MOH}$ in migraine patients. However, no association was observed between CGRP (I/D, rs1553005, rs145837941) and RAMP1 (rs3754701, rs7590387) gene polymorphisms and the aggravation of migraines by medication overuse. Recently, Munksgaard et al. [21] reported that no change in CGRP was detected despite dramatic reduction in headache frequency after the detoxification of $\mathrm{MOH}$ patients, suggesting that 
CGRP is not involved in MOH. Although Cernuda-Morollon et al. [22] reported that CGRP levels in peripheral blood were a biomarker for chronic migraine outside migraine attack times, analgesic overuse did not significantly influence CGRP levels. Therefore, CGRP may be unrelated to $\mathrm{MOH}$ in migraine patients. However, because the small sample size was a limiting factor in the present study, larger genetic studies are required to identify CGRP-related gene fragments that may be associated with $\mathrm{MOH}$ in migraine patients.

\section{Acknowledgments}

We thank Mika Yatagawa, a student at Showa University School of Pharmacy, for her technical assistance. This study was supported in part by a grant from the Private University High Technology Research Center Project with a matching fund subsidy from the Ministry of Education, Culture, Sport, Science, and Technology (MEXT), Japan.

\section{References}

1. Headache Classification Committee, Olesen J, Bousser MG, Diener HC, Dodick D, et al. (2006) New appendix criteria open for a broader concept of chronic migraine. Cephalalgia 26: 742-746. [Crossref]

2. Imai N, Kitamura E, Konishi T, Suzuki Y, Serizawa M, et al. (2007) Clinical features of probable medication-overuse headache: a retrospective study in Japan. Cephalalgia 27: 1020-1023. [Crossref]

3. Kanki R, Nagaseki Y, Sakai F (2008) Medication-overuse headache in Japan. Cephalalgia 28: 1227-1228. [Crossref]

4. Sakai F, Igarashi H (1997) Prevalence of migraine in Japan: a nationwide survey. Cephalalgia 17: 15-22. [Crossref]

5. Kaji Y, Hirata K (2009) Characteristics of mood disorders in Japanese patients with medication-overuse headache. Intern Med 48: 981-986. [Crossref]

6. Goadsby PJ, Edvinsson L, Ekman R (1990) Vasoactive peptide release in the extracerebral circulation of humans during migraine headache. Ann Neurol 28: 183187. [Crossref]

7. Juhasz G, Zsombok T, Modos EA, Olajos S, Jakab B, et al. (2003) NO-induced migraine attack: strong increase in plasma calcitonin gene-related peptide (CGRP) concentration and negative correlation with platelet serotonin release. Pain 106: 461-470.

8. Lassen LH, Haderslev PA, Jacobsen VB, Iversen HK, Sperling B, et al. (2002) CGRP may play a causative role in migraine. Cephalalgia 22: 54-61. [Crossref]

9. Olesen J, Diener HC, Husstedt IW, Goadsby PJ, Hall D, et al. (2004) Calcitonin generelated peptide receptor antagonist BIBN $4096 \mathrm{BS}$ for the acute treatment of migraine. N Engl J Med 350: 1104-1110. [Crossref]
10. Petersen KA, Birk S, Lassen LH, Kruuse C, Jonassen O, et al. (2005) The CGRPantagonist, BIBN4096BS does not affect cerebral or systemic haemodynamics in healthy volunteers. Cephalalgia 25: 139-147. [Crossref]

11. De Felice M, Ossipov MH, Wang R, Lai J, Chichorro J, et al. (2010) Triptan-induced latent sensitization: a possible basis for medication overuse headache. Ann Neurol 67 325-337. [Crossref]

12. Ma W, Zheng WH, Kar S, Quirion R (2000) Morphine treatment induced calcitonin gene-related peptide and substance $\mathrm{P}$ increases in cultured dorsal root ganglion neurons. Neuroscience 99: 529-539.

13. Belanger S, Ma W, Chabot JG, Quirion R (2002) Expression of calcitonin gene-related peptide, substance $\mathrm{P}$ and protein kinase $\mathrm{C}$ in cultured dorsal root ganglion neurons following chronic exposure to mu, delta and kappa opiates. Neuroscience 115: 441453.

14. Menon S, Buteri J, Roy B, Murrell M, Quinlan S, et al. (2011) Association study of calcitonin gene-related polypeptide-alpha (CALCA) gene polymorphism with migraine. Brain Res 1378: 119-124. [Crossref]

15. Sutherland HG, Buteri J, Menon S, Haupt LM, Macgregor EA, et al. (2013) Association study of the calcitonin gene-related polypeptide-alpha (CALCA) and the receptor activity modifying 1 (RAMP1) genes with migraine. Gene 515: 187-192. [Crossref]

16. Onaya T, Ishii M, Katoh H, Shimizu S, Kasai H, et al. (2013) Predictive index for the onset of medication overuse headache in migraine patients. Neurol Sci 34: 85-92. [Crossref]

17. Katsarava Z, Dzagnidze A, Kukava M, Mirvelashvili E, Djibuti M, et al. (2009) Primary headache disorders in the Republic of Georgia: prevalence and risk factors. Neurology 73: 1796-1803. [Crossref]

18. Headache Classification Subcommittee of the International Headache Society (2004) The International Classification of Headache Disorders: 2nd edition. Cephalalgia 24 Suppl 1: 9-160. [Crossref]

19. Diagnostic and Statistical Manual of Mental Disorders. IVth Edition. Washington. American Psychiatric Association Press.

20. Morita A, Nakayama T, Soma M, Mizutani T (2007) Association between the calcitonin-related peptide alpha (CALCA) gene and essential hypertension in Japanese subjects. Am J Hypertens 20: 527-532.

21. Ishii M, Onaya T, Katoh H, Kiuchi Y, Kasai H, et al. (2012) Association between the G252A Tumor Necrosis Factor- $\beta$ Gene Polymorphism and Medication-Overuse Headache. J Clin Neurol 8: 301-304. [Crossref]

22. Munksgaard SB, Frandsen E, Bendtsen L, Jensen RH (2014) EHMTI-0388. Levels of calcitonin-gene related peptide in medication overuse headache - a pilot study. Journal of Headache Pain 15 (Suppl 1): I9.

23. Cernuda-Morollón E, Larrosa D, Ramón C, Vega J, Martínez-Camblor P, et al. (2013) Interictal increase of CGRP levels in peripheral blood as a biomarker for chronic migraine. Neurology 81: 1191-1196. [Crossref]

Copyright: (C2015 Ishii M. This is an open-access article distributed under the terms of the Creative Commons Attribution License, which permits unrestricted use, distribution, and reproduction in any medium, provided the original author and source are credited. 